\title{
Effectiveness of Rituximab in Severe Wegener's Granulomatosis: Report of Two Cases and Review of the Literature
}

\author{
Joaquim Oristrell ${ }^{*}$, Guillermina Bejarano, Rosa Jordana, \\ Manuel Monteagudo, Begoña Marí, Arnau Casanovas \\ and Carles Tolosa
}

\begin{abstract}
Internal Medicine Service, Hospital de Sabadell, Corporació Parc Taulí, Universitat Autònoma de Barcelona (UAB), Spain
\end{abstract}

\begin{abstract}
We hereby describe the satisfactory evolution of rituximab treatment in two patients with Wegener's granulomatosis (WG). Rituximab was indicated for refractoriness to standard treatment in one case and life-threatening myelotoxicity due to alkylating agents in the other. A brief review of previous experience with the use of rituximab in the treatment of WG is presented.
\end{abstract}

Keywords: Rituximab, Wegener's granulomatosis, rescue treatment.

\section{INTRODUCTION}

Wegener's granulomatosis (WG) is a granulomatous inflammation of the upper and lower respiratory tracts, with necrotizing vasculitis affecting small and medium-sized blood vessels and, frequently, necrotizing glomerulonephritis [1]. The introduction of glucocorticoid and cyclophosphamide treatment thirty years ago [2] represented a major step forward in the management of this disease, which had been almost invariably fatal until then. Nonetheless, treatment for $\mathrm{WG}$ is by no means fully satisfactory. As many as $25 \%$ of patients treated with alkylating agents or methotrexate do not achieve complete remission [3-5]. In addition, recurrence rates are between $15 \%$ and $45 \%[6,7]$, and between $20 \%$ and $50 \%$ of patients develop treatment related severe adverse effects $[3,5]$. For all these reasons, research into the treatment of $\mathrm{WG}$ is still ongoing and many treatment protocols have been tested in attempts to reduce the toxicity associated with the prolonged use of alkylating agents [5, 8, 9].

Rituximab is a chimeric monoclonal anti-CD20 antibody which achieves a selective, prolonged depletion of $\mathrm{B}$ lymphocytes. Mainly used for the treatment of B-cell lymphomas, rituximab has recently been used as salvage therapy in the treatment of various refractory autoimmune diseases [10]. Experience with rituximab in WG is limited to short series of patients, and the results have been variable [11-25].

Recently, we have attended two patients with WG in whom rituximab was administrated as rescue medication for refractoriness to standard treatment in one case and lifethreatening myelotoxicity due to alkylating agents in the

*Address correspondence to this author at the Corporació Parc Taulí, Parc Tauli s/n, 08208 Sabadell, Barcelona, Spain; Tel: + 34-937 458 252; Fax: 34-937 160 646; E-mail: joristrell@tauli.cat other. Here we describe the striking response obtained in both cases.

\section{CLINICAL OBSERVATIONS}

\section{- Case 1}

A 43-year old male, smoker of $20 \mathrm{cig} /$ day, was diagnosed of WG in March 1999 due to weight loss, weakness, mild fever, arthralgias, symptoms of nasal obstruction, hemoptysis with bilateral cavitated pulmonary infiltrates, and positive anti-proteinase 3 (anti-PR3) antibodies. Treated with prednisone $(1 \mathrm{mg} / \mathrm{kg} /$ day) and oral cyclophosphamide $(2 \mathrm{mg} / \mathrm{kg} /$ day $)$ the patient gradually recovered, although the immunosuppressive treatment was prolonged for 18 months due to epistaxis, persistently high analytical inflammatory parameters and high anti-PR3 levels. After this period the patient was switched to azathioprine and low dose of steroids, achieving a sustained remission.

In May 2004, epistaxis reappeared, along with monoarthritis of the ankle, a 4-cm pulmonary nodule in the right lower lobe (Fig. 1A) and high anti-PR3 levels. Spirometry showed a mild obstructive pattern (FEV1 74\%), and arterial gasometry on room air revealed a mild hypoxemia. Fiberbronchoscopy with cytologic examination of the bronchoaspirate and a transthoracic puncture of the pulmonary nodule were performed, only revealing necrotic tissue. Higher doses of prednisone along with azathioprine were prescribed. Given the progression of the pulmonary nodule in an active smoker, a lobectomy of the right inferior lobe was finally performed, which confirmed the presence of necrotizing vasculitis consistent with the diagnosis of WG. After surgery the patient presented a severe flare of the disease with the appearance of multiple lung cavities (Fig. 1B) and diplopia due to a sixth cranial nerve palsy. Meningeal thickening consistent with pachymeningitis was found in a Magnetic Ressonance Imaging (MRI). 
(A)

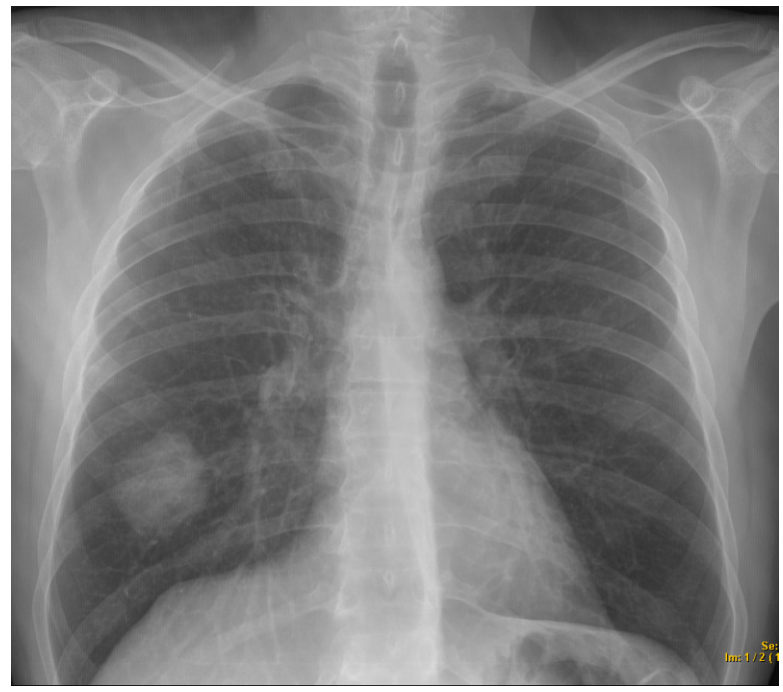

(C1)

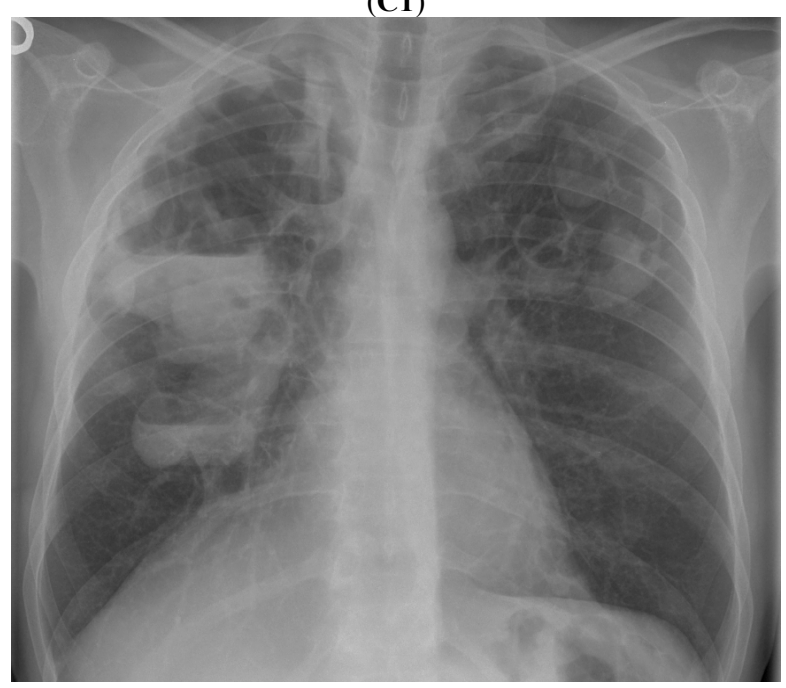

(D1)

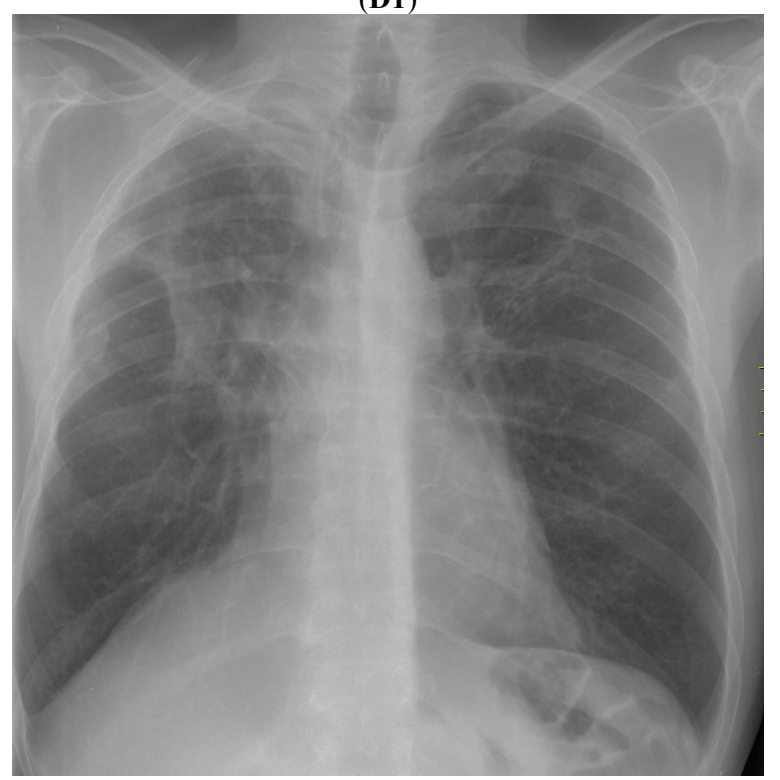

Fig. (1). (A) Observe a solitary lung nodule in the right lower lobe (GW was confirmed by surgical ressection). (B) Multiple cavitated lung nodules. $(\mathbf{C 1}, \mathbf{C 2})$ These chest X-ray and CT images show the progression of the cavitary lesions in spite of the immunosuppressive and antibiotic therapies. (D1, D2) Observe the radiological remission after rituximab administration.
(B)

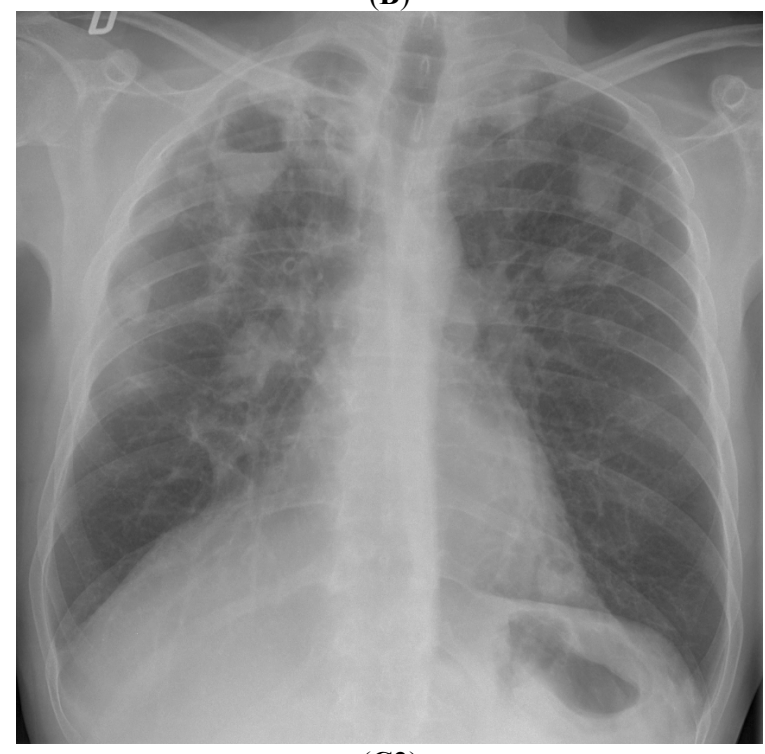

(C2)

(D2)

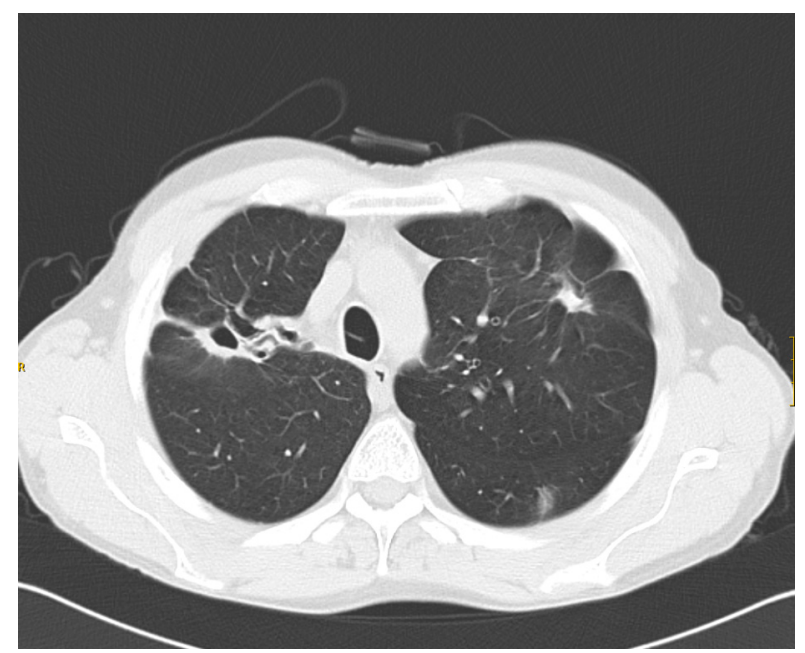

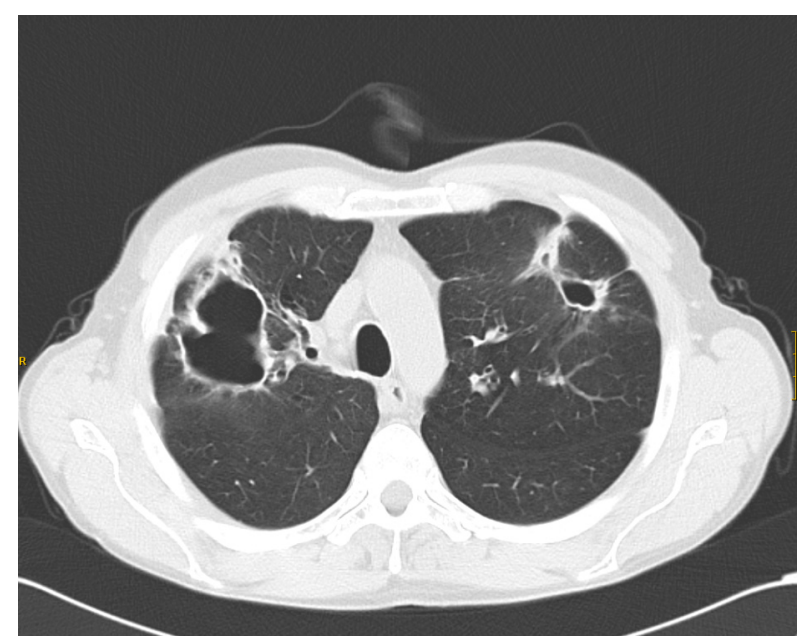


Intravenous cyclophosphamide pulse ( 3 pulses of $500 \mathrm{mg} / \mathrm{m}^{2}$ per month), bolus of 6-methylprednisolone ( $1 \mathrm{~g}$ per day during three consecutive days), intravenous immunoglobulins $(400 \mathrm{mg} / \mathrm{Kg}$ daily during 5 consecutive days) and oral mycophenolate $(1 \mathrm{~g}$ bid) were sequentially administrated without success. In February 2005, due to the persistence of constitutional symptoms and hemoptysis, infliximab was started obtaining a partial clinical and radiological response. However, the drug had to be withdrawn three months later as a result of severe abscessification of the lung cavities which resolved after a long course of parenteral antibiotic treatment.

One year later, in Novembre 2006, the patient presented a new flare of WG with asthenia, enlargement of lung cavities (Fig. 1C), arthralgia, prolonged fever, nodular skin lesions in the lower limbs and appearance of a mononeuritis of the right common peroneal nerve in spite of the patient was receiving maintenance treatment with mycophenolate $(1 \mathrm{~g} / 12 \mathrm{~h})$ and prednisone $(25 \mathrm{mg} / \mathrm{d})$. The patient was treated with four weekly infusions of rituximab $(375 \mathrm{mg} / \mathrm{m} 2)$ together with mycophenolate $(1 \mathrm{~g}$ bid) and prednisone $(40 \mathrm{mg} / \mathrm{d})$.

The patient's response was striking, both clinically and radiologically (Fig. 1D). The analytical inflammatory and immunological parameters also showed a dramatic improvement (Table 1). Twenty-eight months later the patient remains in complete remission, with a notable reduction of the lung cavities, anti-PR3 antibodies remain below $10 \mathrm{U} / \mathrm{ml}$, and levels of circulating $\mathrm{B}$ lymphocytes (CD19) are below 10 cells $/ \mu \mathrm{L}$. The prednisone dose has been progressively tapered to $5 \mathrm{mg} /$ day and is the only maintenance treatment the patient is presently receiving.

Table 1. Activity Markers in the Two Cases of WG, Before and After Rituximab Treatment

\begin{tabular}{|l|c|c|}
\hline \multicolumn{1}{|c|}{ Patient No. 1 } & $\begin{array}{c}\text { Before } \\
\text { Rituximab }\end{array}$ & $\begin{array}{c}\text { 3 Months } \\
\text { After Rituximab }\end{array}$ \\
\hline \hline ESR (mm) & 113 & 33 \\
\hline CRP (mg/dl) & 21,2 & 2,8 \\
\hline Leukocyte count $\left({ }^{*} 10^{-9} / 1\right)$ & 17,200 & 13,670 \\
\hline Hemoblogin (g/l) & 95 & 130 \\
\hline Anti-PR3 (U/1) & 45 & 6 \\
\hline BVAS-WG & 10 & 0 \\
\hline \multicolumn{1}{|c|}{ Patient No. 2 } & $\begin{array}{c}\text { Before } \\
\text { Rituximab }\end{array}$ & $\begin{array}{c}\text { 6 Months } \\
\text { After Rituximab }\end{array}$ \\
\hline ESR (mm) & 129 & 27 \\
\hline CRP (mg/dl) & 12,9 & 0,1 \\
\hline Leukocyte count $\left(* 10^{-9} / 1\right)$ & 15,200 & 8,310 \\
\hline Hemoblogin (g/l) & 92 & 124 \\
\hline Anti-PR3 (U/l) & 22 & 8 \\
\hline BVAS-WG & 17 & 0 \\
\hline $\begin{array}{l}\text { ESR: Erithrocyte sedimentation rate; CRP: C-Reactive protein; Anti-PR3: Anti- } \\
\text { proteinase 3 antibodies; BVAS: Birmingham Vasculitis Activity Score - Wegener's } \\
\text { granulomatosis. }\end{array}$ & & \\
\hline
\end{tabular}

\section{- Case 2}

A 73 year-old male was admitted in May 2007 for study of a pulmonary mass together with asthenia, anorexia, $6 \mathrm{~kg}$ weight loss, mild fever, arthralgia, diffuse abdominal pain, bilateral hypoacusia, right-sided otalgia and cephalea. Physical examination revealed no additional data of interest. Chest X-ray revealed a pulmonary nodule in the right upper lobe and a cranial CT scan showed occupation of the left tympanic cavity compatible with otitis media.

The chest CT scan showed bilateral pulmonary nodules and infiltrates. Spirometry showed a mild mixed ventilatory impairment. Fiberbronchoscopy revealed a diffusely infiltrated tracheobronchial mucosa and a bronchial biopsy disclosed the presence of necrotizing granulomas with negative stains for acid-alcohol resistant bacilli. Analytical tests showed increased values of C-reactive protein and the presence of high-titer anti-PR3 antibodies. A diagnosis of WG was established and oral prednisone $(1 \mathrm{mg} / \mathrm{Kg})$ and a unique bolus intravenous cyclophosphamide $(750 \mathrm{mg} / \mathrm{m} 2)$ with cotrimoxazol prophylaxis were initiated.

In the following days he developed hemoptysis, bilateral pulmonary infiltrates and acute respiratory failure (Fig. 2A). A second fiberbronchoscopy showed a diffuse alveolar hemorrhage. The patient required orotracheal intubation and mechanical ventilation. In the following days, the patient presented abdominal pain in the left iliac fossa and developed peritoneal signs. An urgent laparotomy revealed a mesenteric ischemia and an intestinal perforation. The resection of the ileum, cecum and transverse colon was performed. Other complications that also developed were pancytopenia due to the cyclophosphamide treatment, respiratory infection with MRSA and multiresistant $P$. Aeruginosa, acute renal failure due to acute tubular necrosis requiring hemodialysis, and semi-invasive pulmonary aspergillosis that was effectively treated with voriconazol.

Due to the severity of the WG (with involvement of the lung and gut) and to the presence of active severe infection in a immunocompromised host, the patient was given rituximab $(375 \mathrm{mg} / \mathrm{m} 2$ per week x 4 weeks) with bolus of 6 methylprednisolone $(1 \mathrm{~g} / \mathrm{d}$ x 3$)$ followed by $1 \mathrm{mg} / \mathrm{kg} / \mathrm{day}$ of oral prednisone.

At this point the vasculitis entered in clinical remission, with an important resolution of lung infiltrates (Fig. 2B) and reduction of the inflammatory markers, c-ANCA titers and BVAS-WG score (Table 1), although the patient required a prolonged hospitalization due to the opportunistic infections, a short intestine syndrome with nutritional problems, and muscular atrophy.

Twenty-two months after diagnosis the patient remains stable treated only with a daily prednisone dose of $5 \mathrm{mg} / \mathrm{d}$. Anti-PR3 antibodies remain below $10 \mathrm{U} / \mathrm{ml}$ and $\mathrm{B}$ lymphocyte counts in peripheral blood remain below 10 cells $/ \mu \mathrm{L}$.

\section{DISCUSSION}

To date, rituximab has been used in WG as rescue medication in cases of refractory disease or in cases with a contraindication to cyclophosphamide. At the present moment there is no reliable evidence of the drug's 
Table 2. Previous Reports on the Use of Rituximab in Wegener's Granulomatosis* (In Chronologically Order)

\begin{tabular}{|c|c|c|c|c|c|c|c|c|c|}
\hline Author/Year & Indication & No. pts & Dose & $\begin{array}{l}\text { Previous } \\
\text { Treatment }\end{array}$ & BVAS-GW & $\begin{array}{c}\text { Results on } \\
\text { ANCA Titer }\end{array}$ & $\begin{array}{c}\text { Response } \\
\text { Rate }\end{array}$ & $\begin{array}{l}\text { Follow-Up } \\
\text { (Months) }\end{array}$ & Relapses \\
\hline $\begin{array}{l}\text { Eriksson [12] } \\
2005\end{array}$ & $\begin{array}{l}\text { Refractory/ } \\
\text { relapsing disease }\end{array}$ & 7 & $\begin{array}{c}375 \mathrm{mg} / \mathrm{m} 2 / \mathrm{w} \mathrm{x} \\
2-4 \text { infusions }\end{array}$ & $\begin{array}{l}\text { Prd, Cyc, } \\
\text { Aza, MMF }\end{array}$ & Reduced & Unchanged & $6 \mathrm{CR}, 1 \mathrm{PR}$ & $6-24$ & $2 / 7$ \\
\hline Keogh [13], 2005 & $\begin{array}{l}\text { Refractory } \\
\text { disease or Cyc } \\
\text { intolerance }\end{array}$ & 10 & $\begin{array}{c}375 \mathrm{mg} / \mathrm{m} 2 / \mathrm{w} \mathrm{x} \\
4 \text { infusions }\end{array}$ & $\begin{array}{l}\text { Prd, Cyc, } \\
\text { MTX, MMF }\end{array}$ & Reduced & Decreased & $9 \mathrm{CR}, 1 \mathrm{PR}$ & $10-42$ & $2 / 10$ \\
\hline Omdal [14], 2005 & $\begin{array}{l}\text { Refractory/ } \\
\text { relapsing disease }\end{array}$ & 3 & $\begin{array}{c}375 \mathrm{mg} / \mathrm{m} 2 / \mathrm{w} \mathrm{x} \\
4 \text { infusions }\end{array}$ & $\begin{array}{l}\text { Prd, Cyc, } \\
\text { MTX, MMF, } \\
\text { Aza }\end{array}$ & NS & Decreased & $3 \mathrm{CR}$ & 24 & $3 / 3$ \\
\hline Keogh [15], 2006 & $\begin{array}{c}\text { Refractory } \\
\text { disease or Cyc } \\
\text { intolerance }\end{array}$ & 10 & $\begin{array}{c}375 \mathrm{mg} / \mathrm{m} 2 / \mathrm{w} \mathrm{x} \\
4 \text { infusions }\end{array}$ & $\begin{array}{l}\text { Prd, Cyc, } \\
\text { Aza, MTX }\end{array}$ & Reduced & Decreased & $10 \mathrm{CR}$ & 12 & $1 / 10$ \\
\hline Aries [16], 2006 & $\begin{array}{l}\text { Refractory } \\
\text { disease }\end{array}$ & 8 & $375 \mathrm{mg} / \mathrm{m} 2 / \mathrm{mth}$ & $\begin{array}{l}\text { Prd, Cyc, } \\
\text { MTX, MMF }\end{array}$ & Unchanged & Unchanged & $\begin{array}{l}2 \mathrm{CR}, 1 \mathrm{PR}, \\
5 \text { failures }\end{array}$ & NS & $0 / 8$ \\
\hline Stasi [19], 2006 & $\begin{array}{l}\text { Refractory or } \\
\text { relapsing disease }\end{array}$ & 8 & $\begin{array}{c}375 \mathrm{mg} / \mathrm{m} 2 / \mathrm{w} \mathrm{x} \\
4 \text { infusions }\end{array}$ & $\begin{array}{c}\text { Prd, Cyc, } \\
\text { Aza, MTX, } \\
\text { CyA, Ig, } \\
\text { cotrimoxazol }\end{array}$ & Reduced & Decreased & $\begin{array}{l}7 \mathrm{CR}, \\
1 \mathrm{PR}\end{array}$ & 33 & $3 / 8$ \\
\hline Golbin [25], 2006 & $\begin{array}{l}\text { Refractory or Cyc } \\
\text { contraindicated }\end{array}$ & 21 & $\begin{array}{c}375 \mathrm{mg} / \mathrm{m} 2 / \mathrm{w} \mathrm{x} \\
2-4 \text { infusions }\end{array}$ & Prd & NS & Unchanged & NS & $19-70$ & $7 / 21$ \\
\hline García [10], 2007 & Severe WG & 4 & $\begin{array}{c}375 \mathrm{mg} / \mathrm{m} 2 / \mathrm{w} \times 4 \\
\text { infusions }\end{array}$ & Cyc, Prd & Unchanged & NS & $\begin{array}{c}1 \mathrm{PR}, \\
3 \text { failures }\end{array}$ & NS & $1 / 4$ \\
\hline Henes [16], 2007 & $\begin{array}{l}\text { Refractory } \\
\text { disease }\end{array}$ & 6 & $\begin{array}{c}375 \mathrm{mg} / \mathrm{m} 2 / \mathrm{w} \mathrm{x} \\
4 \text { infusions }\end{array}$ & $\begin{array}{c}\text { Prd, } \\
\text { Leflunom }\end{array}$ & Reduced & Decreased & $\begin{array}{l}5 \mathrm{CR}, \\
1 \mathrm{PR}\end{array}$ & $12-21$ & $1 / 6$ \\
\hline Tamura [17], 2007 & $\begin{array}{l}\text { Refractory } \\
\text { disease }\end{array}$ & 2 & $\begin{array}{c}375 \mathrm{mg} / \mathrm{m} 2 / \mathrm{w} \mathrm{x} \\
4 \text { infusions }\end{array}$ & Prd & Reduced & Normalized & $2 \mathrm{CR}$ & $6-13$ & $1 / 2$ \\
\hline Brihaye [18], 2007 & $\begin{array}{l}\text { Refractory/ } \\
\text { relapsing disease }\end{array}$ & 8 & $\begin{array}{c}375 \mathrm{mg} / \mathrm{m} 2 / \mathrm{w} \mathrm{x} \\
4 \text { infusions }\end{array}$ & $\begin{array}{c}\text { Prd, IS } \\
\text { (not } \\
\text { specified) }\end{array}$ & Reduced & NS & $\begin{array}{c}3 \mathrm{CR}, \\
3 \mathrm{PR}, \\
2 \text { failures }\end{array}$ & NS & $1 / 8$ \\
\hline $\begin{array}{c}\text { Sánchez-Cano } \\
\text { [21], 2008 }\end{array}$ & $\begin{array}{c}\text { Refractory } \\
\text { disease/ Cyc } \\
\text { contraindicated }\end{array}$ & 4 & $\begin{array}{c}375 \mathrm{mg} / \mathrm{m} 2 / \mathrm{w} \mathrm{x} \\
4 \text { infusions }\end{array}$ & $\begin{array}{l}\text { Prd, Cyc, } \\
\text { MTX, Aza }\end{array}$ & Reduced & Decreased & $2 \mathrm{CR}, 2 \mathrm{PR}$ & $8-26$ & $3 / 4$ \\
\hline Sao [29], 2008 & $\begin{array}{l}\text { Refractory } \\
\text { disease or Cyc } \\
\text { intolerance }\end{array}$ & 8 & $\begin{array}{c}375 \mathrm{mg} / \mathrm{m} 2 / \mathrm{w} \mathrm{x} \\
4 \text { infusions }\end{array}$ & $\begin{array}{l}\text { Prd, Cyc, } \\
\text { MTX }\end{array}$ & Reduced & Decreased & $8 \mathrm{CR}$ & NS & $5 / 8$ \\
\hline
\end{tabular}

*Only reports of 2 or more cases.

Prd: Prednisone; Cyc: Cyclophosphamide; Aza: Azathioprine; MTX: Methotrexate; MMF: Mycophenolate; CyA: Cyclosporine A; Ig: Immunoglobulins; Leflunom: leflunomide; NS: Not specified. CR: Complete response. PR: Partial response.

(A)

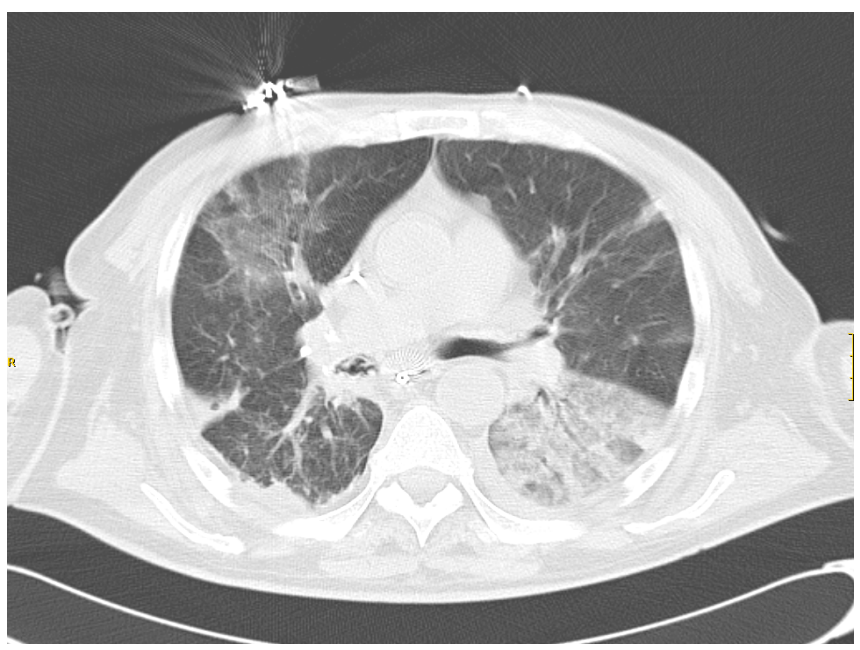

(B)

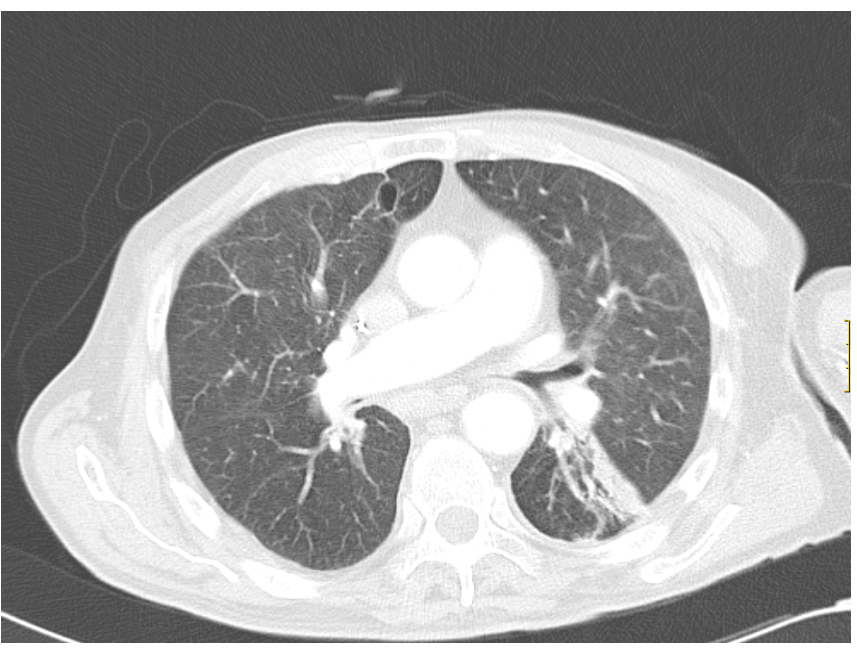

Fig. (2). (A). Extensive lung infiltrates in a patient with WG. (B) After rituximab administration, lung infiltrates mainly disapeared and only residual atlectasis remained in the lef lower lobe. 
effectiveness in WG. About 100 cases of WG treated with rituximab have been reported in the medical literature, in general in small case series (Table 2) [10-25].

Neither of our cases had kidney involvement, but both patients presented serious and life-threatening lung and systemic disease. The first case presented predominantly lung granulomatous and necrotizing disease refractory to multiple immunosuppressive treatments. The second patient presented a rapidly progressive vasculitis with pulmonary hemorrhage, intestinal infarction and complications caused by the administration of bolus cyclophosphamide which limited its subsequent use.

Our patients presented a rapid and effective response to rituximab treatment, as it has been described in several previous reports. We also observed a good response in our first patient, with a predominant granulomatous disease, although some authors have claimed that these patients were refractory to rituximab treatment $[14,16]$.

Both patients remain well and remission-free 28 and 22 months after rituximab infusion. Previous descriptions have shown a relapse rate of $30 \%(29 / 99)$ (Table 2), mainly throughout the first 12 months. Keogh and colleagues [15, 25 ] have described that, commonly, relapses in their patients were preceded by a raising number of circulating B cells and an increase in the anti-PR3 antibodies. Our results are in agreement with these observations since both circulating B cells and anti-PR3 antibodies have remained low.

In conclusion, we believe that rituximab may be an effective alternative for patients with $\mathrm{WG}$ in whom conventional immunosuppressive agents have failed or have contraindications to be used. In the future, the results of several clinical trials currently underway [26-28] will shed more light on the role of rituximab in the treatment of WG.

\section{REFERENCES}

[1] Jennette JC, Falk RJ, Andrassy K, et al. Nomenclature of systemic vasculitides. Proposal of an international consensus conference. Arthritis Rheum 1994; 37: 187-92.

[2] Fauci AS, Katz P, Haynes BF, Wolff SM. Cyclophosphamide therapy of severe systemic necrotizing vasculitis. N Engl J Med 1979; 301: 235-8.

[3] Hoffman GS, Kerr GS, Leavitt RY, et al. Wegener granulomatosis: an analysis of 158 patients. Ann Intern Med 1992; 116: 488-98.

[4] Sneller MC, Hoffman GS, Talar-Williams C, Kerr GS, Hallahan CW, Fauci AS. An analysis of forty-two Wegener's granulomatosis patients treated with methotrexate and prednisone. Arthritis Rheum 1995; 38: 608-13.

[5] Guillevin L, Cordier JF, Lhote F, et al. A prospective, multicenter, randomized trial comparing steroids and pulse cyclophosphamide versus steroids and oral cyclophosphamide in the treatment of generalized Wegener's granulomatosis. Arthritis Rheum 1997; 40 : 2187-98.

[6] Reinhold-Keller E, Fink COE, Herlyn K, Gross WL, de Groot K. High rate of renal relapse in 71 patients with Wegener's granulomatosis under maintenance of remission with low-dose methotrexate. Arthritis Rheum 2002; 47: 326-32.

[7] de Groot K, Rasmussen N, Bacon PA, et al. Randomized trial of cyclophosphamide versus methotrexate for induction of remission in early systemic antineutrophil cytoplasmic antibody-associated vasculitis. Arthritis Rheum 2005; 52: 2461-9.
[8] Langford CA, Talar-Williams C, Barron KS, Sneller MC. A staged approach to the treatment of Wegener's granulomatosis: induction of remission with glucocorticoids and daily cyclophosphamide switching to methotrexate for remission maintenance. Arthritis Rheum 1999; 42: 2666-73.

[9] Jayne D, Rasmussen N, Andrassy K, et al. A randomised trial of maintenance therapy for vasculitis associated with antineutrophil cytoplasmic autoantibodies. New Engl J Med 2003; 349: 36-44.

[10] García Hernández FJ, Ocaña Medina C, González León R, et al. Utilidad del rituximab en el tratamiento de pacientes con enfermedades sistémicas autoinmunitarias. Med Clin (Barc) 2007; 128: 458-62.

[11] Specks U, Fervenza FC, McDonald TJ, Hogan MCE. Response of Wegener's granulomatosis to anti-CD20 chimeric monoclonal antibody therapy. Arthritis Rheum 2001; 44: 2836-40.

[12] Eriksson P. Nine patients with anti-neutrophil cytoplasmic antibody-positive vasculitis successfully treated with rituximab. J Intern Med 2005; 257: 540-8.

[13] Keogh KA, Wylam ME, Stone JH, Specks U. Induction of remission by $\mathrm{B}$ lymphocyte depletion in eleven patients with refractory antineutrophil cytoplasmic antibody-associated vasculitis. Arthritis Rheum 2005; 52: 262-8.

[14] Omdal R, Wildhagen K, Hansen T, Gunnarsson R, Kristoffersen G. Anti-CD20 therapy of treatment-resistant Wegener's granulomatosis: favourable but temporary responses. Scand J Rheumatol 2005; 34: 229-32.

[15] Keogh K, Ytterberg SR, Fervenza F, Carlson KA, Schroeder DR, Specks U. Rituximab for refractory Wegener's granulomatosis. Report of a prospective, open-label pilot trial. Am J Respir Crit Care Med 2006; 173: 180-7.

[16] Aries PM, Hellmich B, Voswinkel J, et al. Lack of efficacy of rituximab in Wegener's granulomatosis with refractory granulomatous manifestations. Ann Rheum Dis 2006; 65: 853-8.

[17] Tamura N, Matsudaira R, Hirashima M, et al. Two cases of refractory Wegener's granulomatosis successfully treated with rituximab. Intern Med 2007; 46: 409-14.

[18] Brihaye B, Aouba A, Pagnoux C, Cohen P, Lacassin F, Guillevin L. Adjunction of rituximab to steroids and immunosuppressants for refractory/relapsing Wegener's granulomatosis: a study on 8 patients. Clin Exp Rheumatol 2007; 25: S23-S7.

[19] Stasi R, Stipa E, del Poeta G, Amadori S, Newland AC, Provan D. Long-term observation of patients with antineutrophil cytoplasmic antibody-associated vasculitis treated with rituximab. Rheumatology 2006; 45: 1432-6.

[20] Henes JC, Fritz J, Koch S, et al. Rituximab for treatment-resistant extensive Wegener's granulomatosis -additive effects of a maintenance treatment with leflunomide. Clin Rheumatol 2007; 26: 1711-5.

[21] Sánchez-Cano D, Callejas-Rubio JL, Ortego-Centeno N. Effect of rituximab on refractory Wegener's granulomatosis with predominant granulomatous disease. J Clin Rheumatol 2008; 14 : 92-3.

[22] Wong CF. Rituximab and antineutrophil cytoplasmic antibodyassociated vasculitis. Granulomatous disease more resistant than vasculitis disease?. J Clin Rheumatol 2008; 14: 61-4.

[23] Ferraro AJ, Day CJ, Drayson MT, Savage CO. Effective therapeutic use of rituximab in refractory Wegener's granulomatosis. Nephrol Dial Transplant 2005; 20: 622-5.

[24] Bachmeyer C, Cadranel JF, Demontis R. Rituximab is an alternative in a case of contra-indication of cyclophosphamide in Wegener's granulomatosis. Nephrol Dial Transplant. 2005; 20: 1274.

[25] Golbin JM, Keogh KA, Fervenza FC, Ytterberg SR, Specks U. Repeated use of rituximab in refractory Wegener's granulomatosis: efficacy for glucocorticoid-free remission maintenance. American College or Rheumatology $70^{\text {th }}$ Annual Scientific Meeting. Washington, November 2006; Abstract 1265.

[26] The European Vasculitis Study Group. RITUXVAS clinical trial protocol. Accessible online on $8^{\text {th }}$ June 2009, in: http://www.vasculitis.org/protocols/ RITUXVAS.pdf 
[27] Immune Tolerance Network. RAVE: rituximab for ANCA-associated vasculitis. Accessible online on $8^{\text {th }}$ June 2009, in: http://www.immune tolerance.org/ RAVE

[28] National Institues of Health. RATTRAP: infliximab versus rituximab in systemic necrotizing vasculitis. Accessible online on $8^{\text {th }}$ June 2009 , in: http://www.clinicaltrials.gov/ct2/show/NCT003 07593

[29] Seo P, Specks U, Keogh KA. Efficacy of rituximab in limited Wegener's granulomatosis with refractory granulomatous manifestations. J Rheumatol 2008; 35: 2017-23.

Received: March 31, 2009

(C) Oristrell et al.; Licensee Bentham Open.

This is an open access article licensed under the terms of the Creative Commons Attribution Non-Commercial License (http://creativecommons.org/licenses/by$\mathrm{nc} / 3.0 /$ ) which permits unrestricted, non-commercial use, distribution and reproduction in any medium, provided the work is properly cited. 